\title{
Vloga in pomen regionalnega razvojnega načrtovanja - primer Gorenjske
}

\author{
Slavka Zupan \\ Mag., Regionalna razvojna agencija Gorenjske, Nosilna organizacija BSC \\ Poslovno podporni center d.o.o. Kranj, Stritarjeva 5, 4000 Kranj, Slovenija \\ e-mail: slavka.zupan@bsc-kranj.si
}

\section{Izvleček}

Pojem regionalni razvoj je $v$ geografski teoriji že dolgo prisoten, medtem, ko se $v$ slovenski praksi pa se $z$ njim $v$ pravem pomenu besede srečujemo šele $v$ zadnjih treh letih, odkar je bil leta 1999 sprejet Zakon o spodbujanju skladnega regionalnega razvoja. Namen prispevka je na primeru Gorenjske predstaviti posledice dosedanjega izvajanja zakona in oceniti njegov vpliv na življenje in konkurenčni položaj regije v Sloveniji.

Ključne besede: regionalni razvoj, regija, pokrajina, regionalna razvojna agencija, regionalni razvojni program, območja s posebnimi razvojnimi problemi

\section{The Role and Importance of Regional Planning - Gorenjska Region}

\begin{abstract}
The term regional development has been present in the geographical theory for a certain period while it is rather new for the slovene practice. The promotion of balanced regional development was introduced by the Act on balanced regional development in 1999. The present article treats the impact and the consequences of the implementation of the act on the life and competitive position of one of the slovene regions, Gorenjska region.
\end{abstract}

Key words: regional development, region, regional development agency, regional development programme 


\section{UVOD}

Pojem regionalni razvoj je v geografski teoriji že dolgo prisoten in uveljavljen, medtem, ko se $\mathrm{v}$ slovenski praksi pa se $\mathrm{z}$ njim $\mathrm{v}$ pravem pomenu besede srečujemo šele v zadnjih treh letih, odkar je bil leta 1999 sprejet Zakon o spodbujanju skladnega regionalnega razvoja (v nadaljevanju zakon). Zakon je po vzoru regionalne strukturne politike držav članic Evropske unije predvidel vzpostavitev razvojnih institucij, pripravo programskih in strateških dokumentov ter ukrepe spodbujanja skladnega regionalnega razvoja, tako na nacionalni kot na regionalni ravni. V skladu s prehodnimi določbami zakona SE do ustanovitve pokrajin regionalna politika izvaja na nivoju 12 statističnih regij. V regijah se nova razvojna politika udejanja od leta 2000 preko regionalnih razvojnih agencij (v nadaljevanju RRA), regionalnih razvojnih programov (v nadaljevanju RRP) in spodbud namenjenih regijam in območjem $\mathrm{z}$ razvojnimi problemi. Praktične izkušnje s pospeševanjem enakomernega regionalnega razvoja snovalci politike kakor tudi njeni izvajalci šele pridobivajo. Namen prispevka je predstaviti posledice dosedanjega izvajanja zakona in njegovega vpliva na življenje in konkurenčni položaj regije v Sloveniji. Za primer sem uporabila statistično regijo - Gorenjsko.

\section{REGIONALNA RAZVOJNA AGENCIJA}

Regionalna razvojna agencija je $\mathrm{v}$ skladu $\mathrm{z}$ določili zakona nosilec in izvajalec regionalne strukturne politike na nivoju statistične regije oz. SKTE $3^{1}$. To pomeni, da je zadolžena za pripravo in spremljanje regionalnih razvojnih programov ter opravljanje drugih razvojnih nalog s področja strukturne politike pri pospeševanju gospodarskega, socialnega, prostorskega in okoljskega razvoja regije. Ustanavljanje RRA-jev je bila prva aktivnost občin oz. že delujočih pospeševalnih organizacij po uveljavitvi zakona. Zakon omogoča različne oblike RRA-jev, zato so $\mathrm{v}$ Sloveniji nastali trije tipi regionalnih razvojnih agencij:

- enoviti tip, kjer je vlogo RRA prevzela obstoječa organizacija za celotno statistično regijo - običajno so bili to regijski pospeševalni centri (Pomurje, Savinjska regije, Zasavje, Posavje, JV Slovenija in Obalno-kraška regija);

- nova RRA, kjer so občine ustanovile novo pravno osebo, ki deluje na območju celotne regije (Osrednjeslovenska regija in Notranjsko-kraška regija);

${ }^{1}$ SKTE - standardna klasifikacija teritorialnih enot v Sloveniji, angl. NUTS; 
- mrežni tip ali pogodbena povezava obstoječih razvojnih organizacij s pooblastilom eni med njimi kot nosilni organizaciji (Goriška, Gorenjska in Podravje).

Na Gorenjskem je nastala mrežna RRA, zato v nadaljevanju posvečam nekaj več pozornosti temu tipu agencije (Karta 1). Vzroke za nastanek agencij mrežnega tipa gre iskati v konkurenci dveh ali več mestnih središč v regiji, obstoju več lokalnih podjetniških centrov ter v nekaterih primerih v netradicionalni in preveliki statistični regiji.

\section{Karta 1: Organiziranost Regionalne razvojne agencije Gorenjske}

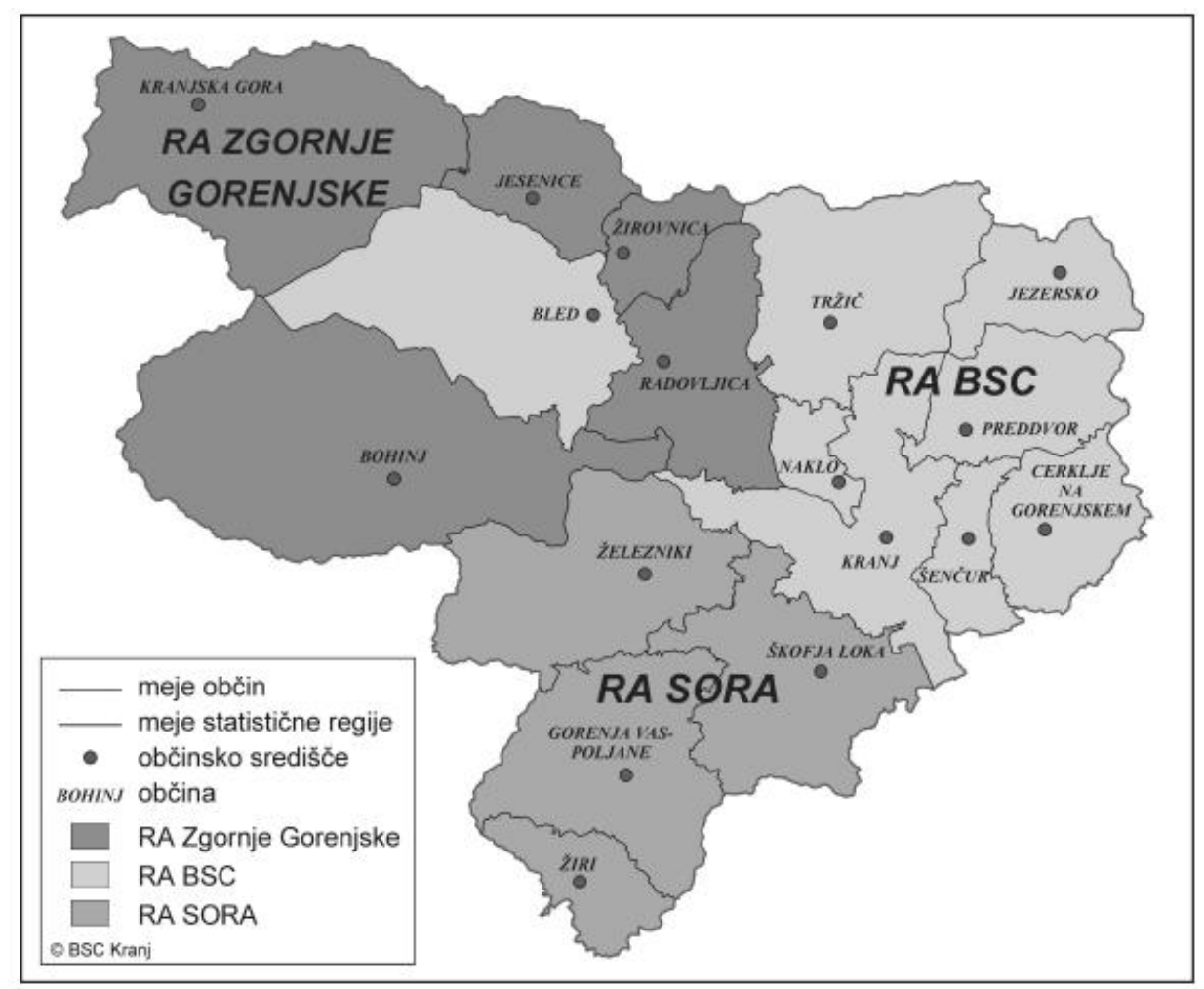

V času uveljavitve zakona so bile v večjih občinah že razvite lokalne razvojne koalicije in registrirani podjetniški centri. Slednji so imeli podporo lokalnih skupnosti, zato le te niso bile navdušene nad ustanavljanjem in financiranjem nove regijske organizacije. Po drugi strani je v vseh treh regijah, ki so se odlo- 
čile za mrežno RRA, občutiti močno željo večjih občin po regijski prevladi. To je še posebej očitno v Podravju, kjer si nasproti stojita Ptuj in Maribor. Na Gorenjskem so to tri občine: Škofja Loka, Kranj in Jesenice, na Goriškem se bije boj med Novo Gorico in vsemi ostalimi: Tolminom, Idrijo in Ajdovščino. Podravje je hkrati še največja statistična regija, kar že samo po sebi otežuje povezovanje.

Preglednica 1: Prednosti in slabosti mrežne RRA na primeru Gorenjske

\begin{tabular}{|c|c|}
\hline Prednosti & Slabosti \\
\hline $\begin{array}{ll}\text { - } & \text { Večja demokratičnost } \\
\text { - } & \text { Nižji stroški } \\
\text { - } & \text { Večja transparentnost } \\
\text { - } & \text { Večja učinkovitost } \\
\text { - } & \text { Bližje »bazi« }\end{array}$ & $\begin{array}{ll}\text { - } & \text { Konflikt vlog in interesov v nosilni organizaciji } \\
\text { - } & \text { Težje osredotočanje na bistvene regijske cilje } \\
\text { - } & \text { Dolgotrajno usklajevanje } \\
\text { - } & \text { Nestalnost onemogoča rast }\end{array}$ \\
\hline
\end{tabular}

Izkušnje Gorenjske dokazujejo, da je mrežna RRA bolj demokratična, ker ima s pogodbo opredeljene "povezovalne« organe in način tesnega sodelovanja med pogodbeno združenimi območnimi agencijami. Nosilna organizacija ima mandat le za določeno obdobje (op. 2 leti v RRA Goriški, 6 let oz. eno programsko obdobje na Gorenjskem), zato si le ta s transparentnim delovanjem in kooperativnim odnosom poskuša status obdržati vnaprej. V mrežni RRA si partnerji projektno delijo delo, zato so učinkovitejši in se bolj približajo lokalnim problemom.

Mrežna organizacija ima tudi svoje slabosti. Ena največjih je konfliktnost vlog in interesov znotraj nosilne organizacije. Vodilna organizacija usklajuje območne razvojne organizacije in programe $\mathrm{v}$ regiji ter istočasno izvaja razvojne naloge na svojem območju. V primeru premajhne kadrovske sposobnosti nosilke, je ta problem še bolj očiten. Mrežna delitev regije otežuje osredotočanje na regijske projekte, ker se interesi pogosto končajo na meji sub-regije. Delno so interesi pogojeni tudi z naravno-geografskimi in družbenimi razlikami znotraj statistične regije (npr. Zgornja Gorenjska s TNP - industrijsko območje Kranja). Organizacijska struktura mrežne RRA je zapletena, zato so procesi odločanja in usklajevanja daljši. Omejenost z mandatom in zgolj pogodbena povezava ne omogočata dolgoročne naravnanosti osrednje regionalne razvojne institucije, zato so po vsej verjetnosti mrežne agencije prehodna faza $\mathrm{v}$ institucionalnem razvoju. Kljub temu velja nekatere prednosti mrežne organizacije vpeljati v ostale RRA-je, saj se prav pomanjkanje demokratičnosti, transparentnosti in povezanosti z območnimi razvojnimi agencijami kaže kot pomanjkljivost velikih, »centraliziranih« RRA-jev. 


\section{OD STATISTIČNE REGIJE K POKRAJINI}

Regionalna razvojna politike se $\mathrm{v}$ prehodnem obdobju do uveljavitve pokrajin izvaja na območju statistične regije. Iz tega izhajajo številne težave, kot so:

- RRA nima političnega sogovornika, ki bi na nivoju regije sprejemal legitimne odločitve. Programski odbor regionalnega razvojnega programa je zasilna rešitev in organ brez lastnega proračuna in politične moči.

- Oteženo je sodelovanje s tujimi partnerji. Večji mednarodni projekti se v alpskih državah (Avstrija, Italija, Švica) odvijajo preko pokrajinskih uprav. Slovenska RRA ne more biti enakovreden partner, še manj občina.

- Na številnih področjih ni regijskih organizacij in s tem nosilcev izvajanja (npr. regijske prostorske zasnove, upravljanje turizma, javnega prometa).

Preglednica 2: Primerjava velikosti statističnih regij v Sloveniji

\begin{tabular}{|c|c|c|c|c|c|c|c|}
\hline \begin{tabular}{|l} 
Statistična \\
regija \\
(SKTE 3) \\
\end{tabular} & $\begin{array}{c}\begin{array}{c}\text { Število } \\
\text { občin } \\
\text { (SKTE 5) }\end{array} \\
\end{array}$ & $\begin{array}{c}\text { Število } \\
\text { prebivalstva }\end{array}$ & $\begin{array}{c}\text { Površina } \\
\left(\mathrm{km}^{2}\right)\end{array}$ & $\begin{array}{c}\text { Gostota } \\
\text { Prebi- } \\
\text { valstva } \\
\end{array}$ & $\begin{array}{c}\text { Indeks } \\
\text { razvojne } \\
\text { ogroženosti }\end{array}$ & \multicolumn{2}{|c|}{ Št. občin v RRP } \\
\hline $\begin{array}{l}\text { Osrednje- } \\
\text { slovenska }\end{array}$ & 24 & 490.148 & 2.555 & 191,8 & 5 & 23 & \begin{tabular}{|l|} 
Litija k \\
Zasavski \\
\end{tabular} \\
\hline Pomurska & 26 & 124.329 & 1.337 & 93,0 & 151 & 26 & \\
\hline Podravska & 34 & 319.717 & 2.170 & 147,3 & 123 & 34 & \\
\hline Koroška & 12 & 74.075 & 1.041 & 71,2 & 99 & 12 & \\
\hline Savinjska & 32 & 256.407 & 2.384 & 107,6 & 106 & 31 & \begin{tabular}{|l} 
Radeče k \\
Zasavski
\end{tabular} \\
\hline Zasavska & 3 & 46.201 & 264 & 175,0 & 112 & 5 & \\
\hline $\begin{array}{l}\text { Spodnje- } \\
\text { posavska }\end{array}$ & 3 & 69.702 & 885 & 78,8 & 147 & 3 & \\
\hline JV Slovenija & 16 & 138.098 & 2.675 & 51,6 & 87 & 16 & \\
\hline Gorenjska & 17 & 196.701 & 2.137 & 92,0 & 35 & 17 & \\
\hline $\begin{array}{l}\text { Notranjsko- } \\
\text { kraška }\end{array}$ & 6 & 50.585 & 1.456 & 34,7 & 91 & 5 & $\begin{array}{l}\text { Il. Bistrica } \\
\text { k Obalno- } \\
\text { kraški }\end{array}$ \\
\hline Goriška & 12 & 120.314 & 2.325 & 51,7 & 48 & 12 & \\
\hline $\begin{array}{l}\text { Obalno- } \\
\text { kraška }\end{array}$ & 7 & 103.817 & 1.044 & 99,4 & 18 & 7 & \\
\hline Slovenija & 192 & 1.990 .094 & 20.273 & 98,2 & 100 & 192 & \\
\hline $\begin{array}{l}\text { Povprečna } \\
\text { statistična } \\
\text { regija }\end{array}$ & 16,0 & $165.841,2$ & $1.689,4$ & & & & \\
\hline
\end{tabular}

Vir: Statistični letopis 2001 in J. Pečar, Regionalni vidiki razvoja Slovenije, Delovni zvezki UMAR, št. 6/X/2001 
- Regionalni razvojni programi so se pripravljali na nivoju SKTE 3, medtem, ko se enotni programski dokument, ki je podlaga za črpanje sredstev strukturnih skladov, pripravlja za celotno državo. Na ta način so se izgubile različne potrebe in prioritete regij, ki so bile opredeljene skozi proces nastajanja RRP. Prav to je v nasprotju $\mathrm{z}$ načeli pristopa od spodaj navzgor.

- Velikost slovenskih statističnih regij je različna in vpliva na uspešnost izvajanja regionalne politike in stopnjo soglasja v regiji. Razmerje števila občin, med najmanjšima statističnima regijama Zasavsko in Spodnjeposavsko regijo in največjo Podravsko regijo, je kar 1: 11,3.

- Najmanjši regiji se po številu občin, obsegu prebivalstva in površini primerjata s sub-regijami večjih statističnih regij (npr. Zgornja Gorenjska, Savinjsko-Šaleška). Zato so prvi RRP-ji nastali v majhnih statističnih regijah, medtem ko se njegova izdelava v Podravju zaključuje po dveh letih.

- Statistične regije povsod ne odražajo tradicionalne pripadnosti in gospodarske gravitacije posameznih območij. Že v fazi priprave RRP-jev se je izkazalo, da nekatere občine »bolj živijo« s sosednjo regijo, zato so se priključile k sosednji RRA.

- Nekatere razvojne teme kot so promet, zavarovana območja, segajo čez dve statistični regiji, instrumenta za usklajevanje ni. Tudi resorna ministrstva te vloge ne opravljajo.

Vse to navaja na dejstvo, da je za uresničevanje politike skladnega regionalnega razvoja v Sloveniji nujna čimprejšnja uveljavitev pokrajin, seveda pod pogojem, da bodo le te razpolagale tudi z razvojnimi sredstvi. Začasna rešitev s statističnimi regijami je dobra učna ura za vzpostavljanje partnerstev med organizacijami ter gospodarstvom. Po drugi strani so občine v teh letih spoznale smisel medsebojnega delovanja in povezovanja $\mathrm{v}$ pokrajine ter pridobile izkušnjo o tem kako velika regija je primerna zanje. Izkušnje Gorenjske kažejo, da gre za primerno veliko regijo, ki se bo v prihodnje lahko uveljavila tudi kot pokrajina. Gorenjska statistična regija sodi med nekoliko nadpovprečno velike slovenske regije, njene meje so dokaj identične zgodovinskim.

Preglednica 3: Osnovni podatki o Gorenjski v primerjavi s Slovenijo

\begin{tabular}{|l|c|c|}
\hline Kazalec & Gorenjska & \% Gorenjske v Sloveniji \\
\hline SKTE raven & SKTE 3 & SKTE 1 \\
\hline Število prebivalcev (leto 2001) & 196.867 & $9,9 \%$ \\
\hline Površina & $2.137 \mathrm{~km}^{2}$ & $9,9 \%$ \\
Gorski svet (nad $600 \mathrm{~m})$ & $70 \%$ & $55 \%$ \\
Nižinski svet (pod 600 m) & $30 \%$ & $45 \%$ \\
\hline Gostota prebivalcev & 92,1 prebivalcev $/ \mathrm{km}^{2}$ & 98,3 prebivalcev $/ \mathrm{km}^{2}$ \\
\hline
\end{tabular}


Vloga in pomen regionalnega razvojnega načrtovanja - primer Gorenjske

\begin{tabular}{|c|c|c|}
\hline Kazalec & Gorenjska & \% Gorenjske v Sloveniji \\
\hline BDP/prebivalca, 1999, v EUR & 10.603 EUR & $\begin{array}{c}(11.504 .85 \text { EUR })^{2} \\
92 \% \text { slovenskega } \\
63 \% \text { EU }\end{array}$ \\
\hline $\begin{array}{l}\text { Število delovno aktivnega } \\
\text { prebivalstva (I. 2002) }\end{array}$ & 70.750 & $9 \%$ \\
\hline Delež zaposlenih v industriji & $51 \%$ & $(42 \%)$ \\
\hline $\begin{array}{l}\text { Delež zaposlenih v storitvenih } \\
\text { dejavnostih }\end{array}$ & $47,9 \%$ & $(52 \%)$ \\
\hline $\begin{array}{l}\text { Število gospodarskih družb } \\
\text { Število zaposelnih v podjetjih in } \\
\text { organizacijah (2001) }\end{array}$ & $\begin{array}{l}3.600 \\
57.474\end{array}$ & $\begin{array}{l}9,5 \% \\
9,5 \%\end{array}$ \\
\hline $\begin{array}{l}\text { Število turistov (2001) } \\
\text { Število nočitev turistov (2001) }\end{array}$ & $\begin{array}{c}433.587 \\
1.332 .014\end{array}$ & $\begin{array}{l}20,8 \% \\
18,7 \%\end{array}$ \\
\hline $\begin{array}{l}\text { Povprečna bruto plača na } \\
\text { prebivalca (dec, 2001) }\end{array}$ & 219.779 SIT & $\begin{array}{l}93 \% \text { slovenskega } \\
\text { povprečja }\end{array}$ \\
\hline Brezposelnost (I., 2002) & $9,0 \%$ & $(12,0 \%)$ \\
\hline
\end{tabular}

Vir: SURS

\section{REGIONALNI RAZVOJNI PROGRAM}

Regionalni razvojni program je osrednji strateški in programski dokument $\mathrm{v}$ katerem naj bi se uskladila razvojna prizadevanja in naloge države in občin na področju gospodarskega, socialnega, prostorskega, okoljskega ter kulturnega razvoja v regiji. Pripravo, sprejem in spremljanje RRP podrobneje predpisuje Navodilo o minimalni obvezni vsebini in metodologiji priprave ter načinu spremljanja in vrednotenja regionalnega razvojnega programa (2000). RRP-ji se načrtujejo za obdobje šestih let, kar je enako programskemu obdobju strukturne politike EU. Regionalne razvojne agencije so se izdelave prvih RRP-jev lotile same ali pa so najele zunanje strokovnjake.

Gorenjska je RRP pripravila $\mathrm{z}$ lastnimi kadri iz vseh treh območnih agencij in ob pomoči irskega strokovnjaka. Zaradi zagotavljanja čim širšega interesa je Regionalni razvojni program Gorenjske 2002 - 2006 nastajal leto in pol v tematskih delovnih skupinah, ki so bile oblikovane na območni in regijski ravni. Vsaka stopnja procesa se je pričela na območju in nadgradila $\mathrm{v}$ regijski obravnavi. Metodološki pristop je temeljil na problemski analizi in oblikovanju drevesa ciljev, postavitvi vizije razvoja, prioritetnih področij ter izvedbenih programov in podprogramov. Takšen pristop se je izkazal za daljšega, morda

\footnotetext{
${ }^{2}$ Številke v oklepaju predstavljajo podatek za Slovenijo.
} 
premalo drznega in vizionarskega, vendar učinkovit in primeren za kasnejše izvajanje.

Med pripravo RRP so se potrdili znani problemi Gorenjske, odprlo pa se je nekaj novih težav kot so:

- veliko število nenadzorovanih vaških in zasebnih vodovodov v Škofjeloškem hribovju in v Karavankah, ki dolgoročno predstavljajo veliko tveganje za zdravje ljudi;

- pomanjkanje koncepta javnega prometa v mestih, alpskih dolinah, celi regiji in v odnosu do Ljubljajne, sosednjih regij in držav;

- neusklajen trg delovne sile,

- neusklajena prostorska politika ponudbe poslovnih in industrijskih površin,

- zapiranje neustreznih živilsko-predelovalnih obratov, še zlasti klavnic, kar ogroža obstoj živinoreje in kmetijstva nasploh;

- težnja po ukinjanju nekaterih javnih služb in storitev na podeželju kot so bencinski servisi, krajevni uradi, podružnične šole;

- šibka regijska identiteta, ki se kaže skozi slabo medsebojno povezanostjo in vplivnostjo regije navzven.

Preglednica 4: Analiza prednosti, slabosti, priložnosti in nevarnosti na ravni Gorenjske

\begin{tabular}{|c|c|}
\hline Prednosti & Slabosti \\
\hline $\begin{array}{ll}- & \text { geostrateška lega } \\
- & \text { naravne danosti: } \\
- & \text { zavarovana območja narave } \\
& \text { (ře zlasti Triglavski narodni } \\
& \text { park), } \\
- & \text { gozd, } \\
- & \text { vode } \\
- & \text { rast prebivalstva } \\
\text { - } & \text { rast prebivalstva } \\
\text { - } & \text { izvozno usmerjeno gospo- } \\
& \text { darstvo } \\
- & \text { pridelava zdrave hrane } \\
\text { - } & \text { bogata kulturna dediščina in } \\
& \text { obstoj kakovostnih regij- } \\
& \text { skih/ lokalnih kulturnih us- } \\
& \text { tanov }\end{array}$ & $\begin{array}{ll}\text { - } & \text { premalo vplivna in prepoznavna v Sloveniji } \\
\text { - } & \text { zaraščanje kmetijskih površin } \\
& \text { cca 8-9 \% podpovprečni ekonomski kazalniki } \\
& \text { zaradi težav pri prestrukturiranju kritičnih starih } \\
\text { - } & \text { neusklustrijskih panog (prim. z RS) } \\
\text { - } & \text { rast BDP / prebivalca stagnira } \\
\text { - } & \text { nizka izobrazbena struktura zaposlenih } \\
\text { - } & \text { neizgrajena kanalizacija s čistilnimi napravami } \\
\text { - } & \text { ter zastareli in nenadzorovani vaški vodovodi } \\
& \text { pomanjkanje finančnih sredstev občin za naložbe } \\
\text { - } & \text { neizdelan sistem javnega potniškega prometa } \\
\text { - } & \text { odmiranje urbanih središč } \\
\text { - } & \text { neusklajen poselitveno-prostorski sistem } \\
\text { - } & \text { pomanjkanje inovativnih razvojnih projektov v } \\
\text { - } & \text { MSP, turizmu in regiji } \\
& \text { premalo »razvojnih« jeder na nivoju podjetij, } \\
\text { - } & \text { občin, občinskih podjetij, zavodov,... } \\
& \text { nepovezanost različnih regijskih institucij }\end{array}$ \\
\hline
\end{tabular}




\begin{tabular}{|l|l|}
\hline Priložnosti & Nevarnosti \\
\hline$\bullet$ & $\begin{array}{l}\text { povezovanje razdrobljenih } \\
\text { institucij, gospodarstva in nji- } \\
\text { hovih znanj } \\
\text { sodelovanje s sosednjimi } \\
\text { regijami in državami } \\
\text { razvoj regijskih investicijsko- } \\
\text { razvojnih fondov/ skladov } \\
\text { prepoznavni regijski in nacio- } \\
\text { nalni simboli, kulturno izroči- } \\
\text { lo slovenstva } \\
\text { (Prešern, Avseniki, Triglav) }\end{array}$
\end{tabular}

Vir: Regionalni razvojni program Gorenjske, 2002-2006.

Izhajajoč iz problemske analize in SWOT je Gorenjska postavila naslednjo razvojno vizijo regije (preglednica 5):

»Gorenjska bo postala dinamična evropska regija, saj bo

- omogočala delo, s tem, da bo spodbujala učenje vseh generacij in konkurenčnost gospodarstva,

- privlačna za bivanje, ker bo skrbela za vzdržen razvoj, varovanje okolja, zdravja in kakovost življenja ter

- privlačna za obiskovanje, ker bo prepoznavna s svojo etnološko, folklorno, literarno, slikarsko idr. tradicijo in ohranjeno alpsko krajino.«

Preglednica 5: Pričakovane kvantitativne spremembe razvojnega stanja Gorenjske 2002 - 2006

\begin{tabular}{|c|c|c|c|}
\hline \multicolumn{2}{|l|}{ Kazalec } & \multirow{2}{*}{$\begin{array}{r}2001 \\
3\end{array}$} & \multirow{2}{*}{$\begin{array}{c}\mathbf{2 0 0 6} \\
\text { Izboljšanje za } \\
\text { pol razreda }(2-3)\end{array}$} \\
\hline $\begin{array}{l}\text { zmanjšanje onesnaženosti } \\
\text { Save (meritveno mesto } \\
\text { Prebačevo pri Kranju) }\end{array}$ & $\begin{array}{c}\text { Razred } \\
\text { onesnaženosti }\end{array}$ & & \\
\hline $\begin{array}{l}\text { rast bruto domačega proizvoda } \\
\text { regije in njegovo približanje } \\
\text { povprečju države }\end{array}$ & $\begin{array}{l}\text { Indeks BDP } \\
\text { Gorenjska/ } \\
\text { Slovenija }\end{array}$ & $\begin{array}{c}92 \% \\
\text { slovenskega } \\
\text { povprečja } \\
\text { (podatek 1999) }\end{array}$ & $\begin{array}{c}97 \% \\
\text { slovenskega } \\
\text { povprečja }\end{array}$ \\
\hline $\begin{array}{l}\text { ohraniti podpovprečno in hkrati } \\
\text { še znižati stopnjo brezposelnosti }\end{array}$ & $\begin{array}{c}\% \\
\text { brezposelnosti }\end{array}$ & $\begin{array}{c}9,0 \% \\
(\text { dec. } 2001)\end{array}$ & $7,5 \%$ \\
\hline $\begin{array}{l}\text { zvišati izobrazbeno raven } \\
\text { zaposlenih in dvigniti nad } \\
\text { slovenskemu povprečju } \\
\text { (stopnje: IV, V, VI, VII, VIII) }\end{array}$ & $\begin{array}{l}\text { \% zaposlenih } \\
\text { po stopnjah } \\
\text { izobrazbe }\end{array}$ & $\begin{array}{l}\text { pod slovenskim } \\
\text { povprečjem }\end{array}$ & $\begin{array}{l}\text { preseči slovensko } \\
\text { povprečje }\end{array}$ \\
\hline $\begin{array}{l}\text { obseg kmetijskih zemljišč se } \\
\text { ne zmanjša }\end{array}$ & Indeks & 100 & 100 \\
\hline
\end{tabular}

Vir: RRP Gorenjske 2002-2006, 2002. 
Uresničevanje vizije in strateških ciljev RRP Gorenjske 2002 - 2006 je opredeljeno v 5 prioritetah, 20 glavnih programih in 62 podprogramih. Na nivoju podprogramov so določeni predlogi ukrepov oz. projektov, indikatorji za spremljanje uresničevanja, nosilne institucije, časovni okvir, geografsko območje izvajanja, aktivnosti v prvih dveh letih in stopnja pomembnosti. Med razvojnimi prioritetami so $\mathrm{v}$ nadaljevanju izpostavljeni podprogrami, ki so ocenjeni z najvišjo stopnjo pomembnosti.

\section{Prioriteta 1: ZAGOTAVLJANJE VZDRŽNEGA RAZVOJA, VAROVANJE OKOLJA IN RAZVOJ INFRASTRUKTURE}

- Uvedba celovitega ravnanja z odpadki v regiji

- Izgradnja manjkajočih kanalizacijskih sitemov, centralnih čistilnih naprav na Tržiški Bistrici in na sotočju Save Dolinke in Save Bohinjke ter malih čistilnih naprav

- Varovanje vodnih virov in prenova zastarelega vodovodnega omrežja

- Pristop k zasnovam regionalnega prostorskega planiranja

- Celovit urbani razvoj

- Izboljšano cestno omrežje, še zlasti povečanje varnosti in pretočnosti na glavnih in povezovalnih cestah s sosednjimi regijami

\section{Prioriteta 2: RAZVOJ GOSPODARSTVA}

- Koordinirana izgradnja poslovnih in obrtnih con v regiji

- Podpora programom gospodarskih ministrstev in EU pri razvoju podjetniškega sektorja in konkurenčnosti

- Podpora projektom povezovanja podjetij v grozde

- Gospodarska promocija regije

- Zasnova regijskega upravljanja in trženja turizma

\section{Prioriteta 3: RAZVOJ ČLOVEŠKIH VIROV}

- Razvoj višješolskega strokovnega izobraževanja v regiji

- Prilagajanje srednješolskega in poklicnega izobraževanja potrebam gospodarstva

- Razvoj instrumentov za usklajevanje potreb na regijskem trgu dela v

- Računalniško opismenjevanje različnih ciljnih skupin in projekti »e-Gorenjska«

- Krepitev razvojnega potenciala in razvojnih jeder v podjetjih in institucijah

- Razvoj zaposlitvenih programov in programov razvoja človeških virov v podjetjih in območjih v krizi ali v prestrukturiranju 


\section{Prioriteta 4: RAZVOJ KMETIJSTVA, GOZDARSTVA IN PODEŽELJA}

- Razvoj, ohranitev, posodobitev in prilagoditev skupnih živilsko-predelovalnih enot

- Organiziranje skupnih oblik trženja kmetijskih produktov

- Spodbujanje razvoja dopolnilnih dejavnosti in alternativnih delovnih mest na podeželju

\section{Prioriteta 5: KREPITEV IDENTITETE REGIJE}

RRP Gorenjske 2002 - 2006 ima svojo vrednost, ker je mobiliziral več kot 250 predstavnikov gospodarstva, občin in javnih organizacij, ki so se na koncu identificirali s programom in ga vzeli za svojega. Proces nastajanja RRP je spodbudil sodelovanje organizacij, ki doslej med seboj niso sodelovale (npr. kmetijstvo, sociala) in motiviral občine, da so se začele pogovarjati o skupnih problemih in povezovati na konkretnih projektih. Hkrati je regija pridobila strategijo, ki odraža njeno dejansko stanje in nakazuje razvojne poti. Pokazalo se je na katerih področjih razvoja regija nima ustreznih struktur in znanj.

\section{PREDNOSTNE REGIJE IN OBMOČJA S POSEBNIMI RAZVOJNIMI PROBLEMI}

Tretji, za regije izredno pomemben element slovenske regionalne politike so državne in mednarodne spodbude, ki se dodeljujejo na podlagi regionalnega razvojnega programa. V skladu z Zakonom o spodbujanju skladnega regionalnega razvoja (1999) se sredstva prednostno usmerjajo v regije, ki po vrednosti bruto domačega proizvoda na prebivalca ali stopnji brezposelnosti za več kot $20 \%$ negativno odstopajo od državnega povprečja in v območja s posebnimi razvojnimi problemi.

Podzakonski akt določa, da so do neposrednih regionalnih spodbud upravičene regije z liste A (Pomurje, Podravje, Zasavje, Spodnje Posavje) in B (Savinjska, Koroška, Notranjsko-kraška, Jugovzhodna Slovenija). Gorenjska se po indeksu razvojne ogroženosti (preglednica 3) uvršča na listo C. Zato je deležna le posrednih spodbud, ki jih za uresničevanje sektorskih nacionalnih politik z razpisi namenjejo posamezna ministrstva. Kavaš (2000) v strokovnih podlagah za takšno razvrstitev regij ugotavlja, da ima Gorenjska v primerjavi $\mathrm{z}$ drugimi regijami neizkoriščene razvojne potenciale. $\mathrm{V}$ analizi so visoko ocenjeni človeški kapital, gospodarska struktura in infrastruktura ter kvaliteta življenja, čeprav je BDP po kupni moči na prebivalca Gorenjske podoben BDP-ju Savinjske ali JV Slovenije. 
Drug instrument so spodbude namenjene območjem s posebnimi razvojnimi problemi, ki so nadomestila nekdanja demografsko ogrožena območja.

Uredba loči ekonomsko šibka območja oziroma občine s podpovrečno bruto osnovo za dohodnino oz. $\mathrm{z}$ upadanjem prebivalstva, občine s strukturnimi problemi v kmetijstvu ali z visoko stopnjo brezposelnosti in razvojno omejevana in obmejna območja. Glede na postavljene kriterije (op. 20 \% negativno odstopanje od državnega povprečja) se le 3 gorenjske občine uvrščajo med območja s posebnimi razvojnimi problemi: Gorenja vas Poljane (ekonomsko šibka občina), Jesenice (območje s strukturnimi problemi - brezposelnost) in Cerklje na Gorenjskem (območje s strukturnimi problemi - kmetijstvo).

Izven sistema spodbud za regionalni razvoj ostajajo vsa preostala območja Gorenjske, med katerimi se nekatera stalno soočajo z resnimi strukturnimi težavami. Pri tem gre izpostaviti industrijska središča v zatonu, kot sta Tržič in precej manjša Kropa ter staranje prebivalstva in opuščanje kmetovanja v hribovitih območjih Karavank, Julijskih Alp in Škofjeloškega hribovja.

Preglednica 6: Območja s posebnimi razvojnimi potrebami znotraj Gorenjske

\begin{tabular}{|l|l|l|}
\hline Tip območja & Razvojna potreba & Območje \\
\hline $\begin{array}{l}\text { Industrijska območja } \\
\text { v krizi }\end{array}$ & $\begin{array}{l}\text { Prestrukturiranje gospodarstva } \\
\text { Pospeševanje zaposlovanja }\end{array}$ & $\begin{array}{l}\text { Jesenice, Tržič, Gorenja vas } \\
\text { Poljane }\end{array}$ \\
\hline $\begin{array}{l}\text { Urbana območja in } \\
\text { mestna jedra }\end{array}$ & $\begin{array}{l}\text { Celovita ekonomska, } \\
\text { urbanistična, prostorska in } \\
\text { socialna prenova }\end{array}$ & $\begin{array}{l}\text { Kranj, Škofja Loka, Tržič, } \\
\text { Radovljica, Jesenice }\end{array}$ \\
\hline $\begin{array}{l}\text { Zavarovana območja } \\
\text { narave- Triglavski } \\
\text { narodni park, bodoči } \\
\text { regijski park Karavanke, } \\
\text { Kamniško - Savinjske Alpe }\end{array}$ & $\begin{array}{l}\text { Sonaravni razvoj turizma, } \\
\text { kmetijstva in podjetništva }\end{array}$ & $\begin{array}{l}\text { Bohinj, Bled, Kranjska gora in } \\
\text { ostala naselja znotraj drugih } \\
\text { zavarovanih območij narave }\end{array}$ \\
\hline $\begin{array}{l}\text { Hribovita območja } \\
\text { Razvoj dodatnih dejavnosti } \\
\text { na podeželju } \\
\text { Razvoj infrastrukture } \\
\text { Preprečevanje zaraščanja } \\
\text { krajine }\end{array}$ & $\begin{array}{l}\text { Škofjeloško hribovje, Kara- } \\
\text { vanke in Kamniško Savinjske } \\
\text { Alpe (Jezersko, Preddvor, } \\
\text { deloma Žirovnica, Jesenice, } \\
\text { Cerklje, Radovljica) }\end{array}$ \\
\hline $\begin{array}{l}\text { Ravninska območja z inten- } \\
\text { zivnejšo kmetijsko rabo in } \\
\text { pritiskom na rabo prostora }\end{array}$ & $\begin{array}{l}\text { Usklajen razvoj med konflikti } \\
\text { razvojnih interesov: kmetijstvo } \\
\text {-promet - industrija }\end{array}$ & $\begin{array}{l}\text { Naklo, Šenčur, Cerklje na } \\
\text { Gorenjskem, Škofja Loka, } \\
\text { Kranj, Radovljica }\end{array}$ \\
\hline
\end{tabular}

\section{ZAKLJUČEK}

Po dveh letih od uveljavitve Zakona o spodbujanju skladnega regionalnega razvoja (1999) so vzpostavljeni vsi instrumenti in strukture regionalne politike. Regionalnim razvojnim agencijam se je uspelo uveljaviti v življenju svojih 
regij, še posebej v odnosu do občin in javnih služb, različno uspešne pa so bile pri vključevanju gospodarstva, socialnih partnerjev in civilne družbe.

RRA-ji so z regionalnimi razvojnimi programi uspeli aktivirati razvoj regij od spodaj navzgor ter tako oblikovati osrednji programski dokument regije za obdobje 2002 - 2006. Obstaja vprašanje kako bo RRA-jem uspelo ohraniti aktivnost in motiviranost partnerjev skozi celotno programsko obdobje ter uresničiti zastavljene cilje. Dejstvo je, da so prvi razvojni programi zelo obsežni, ker so v njih pripravljalci zajeli vse probleme regije, rangiranje in soglasje o manjšem številu regijskih projektov pa je uspelo le v nekaterih regijah. Regionalni razvojni programi za naslednje programsko obdobje 2007 - 2013 bodo vsekakor krajši, enostavnejši, bolj vizionarski in hkrati konkretnejši, ker bodo temeljili na izkušnji izvajanja današnjih programov.

Na prihodnji razvoj regionalnih razvojnih agencij kot institucij bo močno vplivalo nastajanje pokrajin, dostopnost regije do programskih spodbud države in EU ter bolj jasna opredelitev statusa in pristojnosti RRA. Izhajajoč iz trenuthe razvojne situacije in politike države je sklepati, da bodo z zakonom določeno vlogo $\mathrm{v}$ svojem prostoru lažje uveljavile razvojne agencije $\mathrm{v}$ vzhodni Sloveniji, kamor se v letih 2003 in 2004 usmerjajo vse neposredne proračunske spodbude za regionalni razvoj. RRA-ji v zahodni in osrednji Sloveniji, kjer se nahaja tudi RRA Gorenjske, bodo v prihodnje še bolj usmerjeni na trg, $\mathrm{k}$ podjetjem in občinam ter $\mathrm{v}$ iskanje zasebno-javnih in mednarodnih projektnih partnerstev. Tako lahko pričakujemo, da bosta $\mathrm{v}$ prihodnje nastala $\mathrm{v}$ Sloveniji dva modela pristopov k regionalnemu razvoju: »vzhodni« vezan na podporo in neposredna sredstva države in drugi, »zahodni«, ki bo svoj obstoj temeljil predvsem na aktiviranju endogenih virov, trgu in projektnem mreženju. Čas bo pokazal ali bodo s takšno regionalno politiko vse slovenske regije napredovale, ali se bodo razvojne razlike med njimi in EU zmanjšale ali se bodo današnja razmerja spremenila.

\section{Literatura in viri:}

Kavaš, D., Strmšnik, I., Pečar J., 2000. Reforma slovenske regionalne struturne politike. V: Geographica Slovenica 33 II, Ljubljana, 83-132.

Kavaš, D., Izkoriščanje regionalnih razvojnih potencialov in ocena razvojnih možnosti statističnih regij. Primerjalna analiza, delovno gradivo, 2000.

Navodilo o minimalni obvezni vsebini in metodologiji priprave tr načinu spremljanja in vrednostenja regionalnega razvojnega programa. Uradni list RS št. 52, 2000.

Navodilo o prednostnih območjih dodeljevanja spodbud, pomembnih za skladni regionalni razvoj. Uradni list RS št. 44, 2001. 
Navodilo o prednostnih območjih za dodeljevanje spodbud pomembnih za skladni regionalni razvoj. Uradni list RS št. 44, 2001.

Pečar, J., 2001. Regionalni vidiki razvoja Slovenije. V: Delovni zvezek Urada za makroekonomske analize in razvoj, 6/X, 160.

Pravilnik o dodeljevanju regionalnih državnh pomoči ter regionalnih razvojnih spodbud samoupravni lokalnim skupnostim in regionalnim razvojnim agencijam. Uradni list RS št.. 62, 20001.

Pravilnik o organizaciji in pogojih za opravljanje nalog regionalne razvojne agencije. Uradni list RS št. 44, 2001.

Pravilnik o organizaciji in pogojih za opravljanje nalog regionalne razvojne agencije. Uradni list RS št. 52, 2000.

Pravilnik o regionalni karti za izvajanje politike regionalnih državnih pomoči v Republiki Sloveniji. Uradni list RS št.. 8, 2001.

Regionalni razvojni program Gorenjske 2002 - 2006. RRA Gorenjske, nosilna organizacija BSC Kranj, marec 2002.

Uredba o namenih in pogojih za dodeljevanje državnih pomoči ter določitvi pristojnosti ministrstev za upravljanje posameznih shem državnih pomoči. Uradni list RS št. 59, 2000.

Uredba o standardni klasifikaciji teritorialnih enot. Uradni list RS št.. 28, 2000.

Uredba o vrednostih meril za določitev območij s posebnimi razvojnimi problemi in določitvi območij, ki izpolnjujejo ta merila. Uradni list RS št. 59, 2000.

Zakon o spodbujanju skladnega regional. razvoja. Uradni list RS št.. 60, 1999.

\section{THE ROLE AND IMPORTANCE OF REGIONAL PLANNING/ GORENJSKA REGION}

\section{Summary}

The term regional development has been present in the geographical theory for a certain period while it is rather new for the slovene practice. The promotion of balanced regional development was introduced by the Act on balanced regional development in 1999 based on the experiences of the european regional policy. As Slovenia has not established provinces yet the statistical regions are used for adoption of regional policy on NUTS 3 level until that.

Following the above three key elements needed to be applied in each of the 12 slovene statistical regions in the last years. These are: i) structure in the form of Regional Development Agency (RDA); ii) strategy called Regional Development Programme for the period 2000-2006 (RDP) and iii) incentives. The present article treats the impact and the consequences of the implementa- 
tion of the a.m. act on the life and competitive position of one of the slovene regions, Gorenjska region.

\section{Regional Development Agency}

There were three different types of RDAs established in the regions: i) single RDA for 1 statistical region usually developed out of previous ex-business centre ( Pomurje, Savinjska, Zasavje, Posavje, JV Slovenia, Obalno-kraška); ii) newly established single RDAs (Osrednjeslovenska region, Notranjskokraška); iii) RDA as a network of existing local development agencies with a leading mandate giving to one of them (Goriška, Gorenjska, Podravje). Gorenjska formed network type of RDA. Generally network type of RDAs are more democratic and transparent, more effective and efficient, cost less and they are usually closer to the local needs. On the other hand the conflict of regional and local interests within the lead organisation, lack of focus on regional goals, longstanding reconciliation and variability of lead partner jeopardise such RDA in a longer term. These are the reasons why we see this type of RDA as a transitional only.

\section{From Statistical Region towards Province}

Regional development is being curently implemented within the statistical regions. This inhibits the efficiency of RDAs as there exists no political authority, no decision-makers and regional budgets. Apart from that regions miss structures for specific fields of regional co-operation like tourism, energy, public transport, etc. In addition, the size of statistical regions regarding the number of municipalities varies in the ratio 1: 11,3. Some of the municipalities preferred to join RDP of neighbouring region. This implies the fact that establishment of provinces will mitigate the effective implementation of regional policy in the slovene regions. Being close to its historical boundaries and of the average size in number of municipalities (17) and in the population (196.716) the case of Gorenjska shows that this is apropriate size of the future province.

\section{Regional Development Programme}

Regional Development Programme (RDP) is the central strategic and programming document of any of 12 regions. Its preparation was launched for the first time for the period $2000-2006$ by the new law and its subsidiary acts. RDAs were entitled to prepare RDP for their regions. While some of them engaged consultant companies for this task, the majority including RDA Gorenjska, managed the RDP process by itselves. In order to demonstrate broad regional partnership and asses the real needs and opportunities of Gorenjska region 12 sub-regional and 4 regional working groups were organised in four 
priority fields: sustainable development and infrastructure, economic development, human resource development and rural development. Through problem analysis the vision, objective tree and operational programme were set up.

\section{Regions and areas with special development problems}

The last but not the least important element of the slovene regional policy is the national and international incentives to the regions which shall be based on RDPs. As per the act only A and B regions whose GDP or employment rate is $20 \%$ bellow the national average and municipalities with special development problems can benefit from these incentives. Gorenjska being listed $\mathrm{C}$ region is not entitled upon incentives for balanced regional development while only three out of 17 municipalities are determined as areas with special development problems in Gorenjska (Jesenice, Gorenja vas-Poljane, Cerklje na Gorenjskem). Relying on the statistics the existing Slovene regional policy left aside some areas which are facing economic decline for a decade (like Tržič, Kropa and mountain areas within Triglav National Park, Karavanke, surroundings of Škofja Loka) and which redevelopment is crucial for the future of the region.

Nevertheless, that structures and instruments of regional policy are in place after two years from the adoption of the law on balanced regional development. RDAs placed themselves into the life of the regions and they managed to set up regional partnerships and strategies. There is a questionmark how far they will be able to keep the enthusiasm of the partners and how far RDPs will be implemented as they are very complex. The future position of RDAs will depend on the formation of provinces and accessibility to national and international funds. On the basis of existing policy it is expected that two models of regional development approach may develop in the future: "east" and "west" model. Due to forcasted allocation of funds to the less developed slovene regions, RDAs in the east part of Slovenia (A and B regions) will be privileged in positioning themselves within their regions, while RDAs from west part of Slovenia will depend more on the market, endogenues sources and close collaboration with businesses. The time will prove whether all slovene regions will improve their competitive position or the regional disparities will decrease or the proportions among regions will change as a result of this concept. 